\title{
TINJAUAN NORMATIF PERLINDUNGAN HUKUM TERHADAP ISTRI KORBAN KEKERASAN DALAM RUMAH TANGGA
}

\author{
Dian Ety Mayasari \\ Fakultas Hukum Universitas Katolik Darma Cendika \\ Korespondensi: demasari2006@yahoo.co.id
}

\begin{abstract}
Abstraksi
Seorang istri yang menjadi korban kekerasan dalam rumah tangga dengan pelaku adalah suaminya sendiri menunjukkan adanya ketidakseimbangan hak dan kewajiban antara suami dan istri dalam menjalani kehidupan berumah tangga, padahal hak dan kewajiban suami istri sudah diatur secara tegas dalam Undang-Undang Nomor 1 Tahun 1974 tentang Perkawinan. Sebagai pelaku tindak kekerasan dalam rumah tangga maka suami tidak dapat lepas dari sanksi pidana yang sudah ditentukan dalam Undang-Undang Nomor 23 Tahun 2004 tentang Penghapusan Kekerasan Dalam Rumah Tangga, oleh sebab itu istri sebagai korban yang mengalami kerugian dari terjadinya kekerasan dalam rumah tangga harus berani untuk mengadukan tindakan suaminya ke pihak kepolisian agar bisa diproses secara hukum dengan harapan apabila sudah dijatuhkan sanksi pidana bisa memberi efek jera pada pelaku sehingga tidak akan mengulangi lagi perbuatannya dan tujuan perkawinan bisa tercapai.
\end{abstract}

Kata Kunci: Istri, Suami, Kekerasan Dalam Rumah Tangga.

\begin{abstract}
Domestic violence perpetrated by a husband to his wife reflects the absence of balanced rights and obligations in the household as stipulated in Law No. 1 of 1974 on Marriage. Although it occurs within the domestic sphere, the husband who perpetrates domestic violence does not escape from the threat of criminal sanctions as stipulated in Law No. 23 of 2004 on the Elimination of Domestic Violence. Therefore, a wife who becomes a victim of domestic violence should not hesitate to file a report with the relevant police department concerning her husband's abusive action so that legal proceedings are performed and ultimately criminal sanctions conferred. It is expected that the criminal sanction provides a deterrent effect. Hopefully, the perpetrator will not repeat his actions and thus the purpose of creating a happy family in a marriage can be achieved.
\end{abstract}

Keywords: Wife; Husband; Domestic Violence. 


\section{PENDAHULUAN}

Tujuan terjadinya perkawinan sebagaimana yang ditentukan dalam Pasal 1 Undang-Undang Nomor 1 Tahun 1974 tentang Perkawinan (selanjutnya disingkat dengan UndangUndang Perkawinan) adalah untuk membentuk keluarga (rumah tangga) yang bahagia dan kekal berdasarkan ketuhanan Yang Maha Esa. Bahagia dalam berumah tangga artinya ada kerukunan yang menciptakan rasa tenteram, damai, dan saling menyayangi tanpa saling mencurigai. ${ }^{1}$ Sedangkan kekal dalam berumah tangga artinya sekali perkawinan dilaksanakan, berlangsung terus tidak boleh diputuskan begitu saja. ${ }^{2}$ Untuk mewujudkan tujuan perkawinan, maka Undang-Undang Perkawinan menentukan syarat terjadinya perkawinan yang harus dipenuhi, yaitu syarat materiil dan syarat formil. Syarat materiil disebut juga syarat intern yang berkaitan dengan pihak yang akan melaksanakan perkawinan dan syarat formil disebut juga syarat ekstern yang berkaitan dengan formalitas-formalitas dalam pelaksanaan perkawinan. ${ }^{3}$

Syarat materiil dalam perkawinan meliputi (1) persetujuan kedua belah pihak; (2) izin dari kedua orang tua apabila belum mencapai umur 21 tahun; (3) pria berumur 19 tahun dan wanita 16 tahun, pengecualiannya yaitu ada dispensasi dari pengadilan atau camat atau bupati; (4) kedua belah pihak dalam keadaan tidak kawin; dan (5) wanita yang kawin untuk kedua kalinya harus lewat masa tunggu (iddah). Bagi wanita yang putus perkawinannya karena perceraian, masa iddahnya 90 hari dan karena kematian 130 hari. ${ }^{4}$ Syarat formil perkawinan meliputi (1) harus mengajukan laporan ke Pegawai Pencatat Nikah, Talak, dan Rujuk; (2) pengumuman yang ditanda tangani oleh Pegawai Pencatat yang memuat (a) nama, umur, agama/kepercayaan, pekerjaan, tempat kediaman dari calon mempelai dan dari orang tua calon. Di samping itu, disebutkan juga nama istri atau suami yang terdahulu; (b) hari, tanggal, jam, dan tempat perkawinan dilangsungkan. ${ }^{5}$

Keluarga yang dibentuk lewat perkawinan antara seorang pria dengan seorang wanita, dan setelah melakukan perkawinan, akibat hukumnya masing-masing mempunyai posisi sebagai suami dan istri, apabila awal mereka kawin didasarkan pada persetujuan yang berarti mencerminkan adanya persamaan kedudukan, maka menjadi layak kalau setelah kawin posisi mereka sebagai suami dan istri juga harus seimbang. ${ }^{6}$ Keseimbangan

\footnotetext{
I Ketut Oka Setiawan, Hukum Perorangan dan Kebendaan (Sinar Grafika 2016) 45. Ibid.

Salim H.S., Pengantar Hukum Perdata Tertulis (BW) (Sinar Grafika 2014) 62.

Ibid.

Ibid.63.

Moch. Isnaeni, Hukum Perkawinan Indonesia (Revka Petra Media 2016) 61.
} 
ini terwujud karena salah satu syarat materiil terjadinya perkawinan yaitu adanya kesepakatan bersama antara pihak pria dan wanita. Kesepakatan dalam perkawinan diatur dalam Pasal 6 ayat (1) Undang-Undang Perkawinan yang menentukan perkawinan harus didasarkan atas persetujuan kedua calon mempelai.

Menurut Wirjono Prodjodikoro kalau seorang perempuan dan seorang laki-laki berkata sepakat untuk melakukan perkawinan satu sama lain, ini berarti mereka saling berjanji akan taat pada peraturan-peraturan hukum yang berlaku mengenai kewajiban dan hak masing-masing pihak selama dan sesudah hidup bersama itu berlangsung, dan mengenai kedudukannya dalam masyarakat dari anak-anak keturunannya. ${ }^{7}$ Dengan demikian, setelah terjadi kesepakatan diantara kedua belah pihak mengakibatkan adanya hak dan kewajiban antara suami istri dalam hidup berumah tangga.

Mencapai tujuan perkawinan tidak mudah, ada kalanya di dalam menjalani rumah tangga ada perselisihan pendapat, sebagai contoh salah satu pihak lalai menjalankan kewajibannya dan terjadi tindakan kekerasan dalam rumah tangga apabila tidak adanya rasa saling mengalah diantara suami istri. Istri yang menjadi korban kekerasan dalam rumah tangga menempatkan istri dalam posisi yang tidak seimbang dengan adanya domi- nasi suami dalam berumah tangga dan mengakibatkan berkurangnya peranan istri dalam urusan rumah tangga.

Pemerintah Indonesia sudah mengesahkan adanya Undang-Undang Nomor 23 Tahun 2004 tentang Penghapusan Kekerasan Dalam Rumah Tangga (selanjutnya disingkat dengan Undang-Undang Penghapusan Kekerasan Dalam Rumah Tangga) yang salah satu tujuan pengesahannya bahwa korban kekerasan dalam rumah tangga yang kebanyakan adalah perempuan harus mendapat perlindungan dari negara dan/atau masyarakat agar terhindar dan terbebas dari kekerasan atau ancaman kekerasan, penyiksaan, atau perlakuan yang merendahkan derajat dan martabat kemanusiaan. Dalam rangka mencegah terjadinya kekerasan dalam rumah tangga selain ada UndangUndang Penghapusan Kekerasan Dalam Rumah Tangga juga harus dipahami hak dan kewajiban suami istri dalam berumah tangga yang diatur dalam Undang-Undang Perkawinan. Oleh sebab itu penulisan ini akan membahas mengenai terjadinya kekerasan dalam rumah tangga menyebabkan tidak terlaksananya hak dan kewajiban suami istri dalam berumah tangga, dan bentuk-bentuk kekerasan yang dialami oleh istri dan sanksi bagi suami sebagai pelaku kekerasan.

\footnotetext{
Muhammad Syaifuddin, dkk., Hukum Perceraian (Sinar Grafika 2016) 3-4.
} 


\section{PEMBAHASAN}

Terjadinya Kekerasan Dalam Rumah Tangga Mengakibatkan Hak dan Kewajiban Suami Istri Tidak Dapat Terlaksana

Ketentuan Pasal 28G ayat (1) Undang-Undang Dasar 1945 bahwa setiap orang berhak atas perlindungan diri pribadi, keluarga, kehormatan, martabat, dan harta benda yang di bawah kekuasaannya, serta berhak atas rasa aman dan perlindungan dari ancaman ketakutan untuk berbuat atau tidak berbuat sesuatu yang merupakan hak asasi. Selanjutnya Pasal 28G ayat (2) bahwa setiap orang berhak untuk bebas dari penyiksaan atau perlakuan yang merendahkan derajat martabat manusia dan berhak memperoleh suaka politik dari negara lain. Berdasarkan ketentuan UndangUndang Dasar 1945 tersebut diketahui seorang istri mempunyai hak untuk hidup dalam perkawinan yang bebas dari tindakan penyiksaan, adanya tindak kekerasan dalam rumah tangga merupakan pelanggaran ketentuan Undang-Undang Dasar 1945 karena seorang istri dalam perkawinan mempunyai hak yang sama dengan suami yang ditentukan dalam Pasal 51 ayat (1) Undang-Undang Nomor 39 Tahun 1999 tentang Hak Asasi Manusia (selanjutnya disingkat dengan UndangUndang Hak Asasi Manusia) bahwa seorang istri selama dalam ikatan perkawinan mempunyai hak dan

Ibid. 386.

Ibid. tanggung jawab yang sama dengan suaminya atas semua hal yang berkenaan dengan kehidupan perkawinannya, hubungan dengan anakanaknya, dan hak kepemilikan serta pengelolaan harta bersama.

Perkawinan adalah suatu perjanjian yang menimbulkan perikatan antara suami dan istri, yang menempatkan suami dan istri dalam kedudukan yang seimbang dan mengandung hak dan kewajiban yang seimbang pula bagi kedua belah pihak. ${ }^{8}$ Adanya kesepakatan antara pihak pria dan wanita sebagai syarat materiil dalam perkawinan menunjukkan pihak pria dan wanita mengetahui sekaligus menyetujui akibat hukum yang lahir dari perkawinan, yaitu adanya hak dan kewajiban suami dan istri dalam perkawinan. Yang dimaksud dengan hak adalah suatu yang merupakan milik atau dapat dimiliki oleh suami atau istri yang diperolehnya dari hasil perkawinannya, sedangkan kewajiban adalah hal-hal yang wajib dilakukan atau diadakan oleh salah seorang dari suami istri untuk memenuhi hak dari pihak lain. ${ }^{9}$

Pasal 30 Undang-Undang Perkawinan menentukan suami istri memikul kewajiban yang luhur untuk menegakkan rumah tangga yang menjadi sendi dasar dari susunan masyarakat. Pasal 31 ayat (1) UndangUndang Perkawinan menentukan hak dan kedudukan istri adalah seimbang dengan hak dan kedudukan suami dalam kehidupan rumah tangga dan pergaulan hidup bersama dalam 
masyarakat. Ketentuan Pasal 30 dan Pasal 31 ayat (1) tersebut menunjukkan bahwa suami istri mempunyai kesempatan yang sama untuk terlibat dan berinteraksi dalam kehidupan bermasyarakat, intinya suami istri mempunyai hak dan kewajiban yang sama dalam kehidupan bermasyarakat tanpa membedakan jenis kelamin. Demikian pula dalam melakukan perbuatan hukum, suami istri mempunyai hak yang sama yang diatur dalam Pasal 31 ayat (2) Undang-Undang Perkawinan yaitu masing-masing pihak berhak untuk melakukan perbuatan hukum. Gejolak emansipasi yang dinyalakan oleh kaum wanita sengaja ditampung dalam ketentuan Pasal 31 ayat $(2) \cdot{ }^{10}$

Pasal 31 ayat (3) Undang-Undang Perkawinan menentukan suami adalah kepala keluarga dan istri sebagai ibu rumah tangga. Peran istri sebagai ibu rumah tangga dapat dikategori sebagai peranan dalam intern keluarga namun tidak dapat diremehkan. Meskipun hanya berperan sebagai ibu rumah tangga mereka bertindak sebagai "pendamping" suami, sebagai mitra sejajar dan bukan lagi sekedar menjadi "konco wingking" (teman belakang), padahal tidak dapat dipungkiri justru perannya dalam sektor domestik tersebut mampu menjadi motivator bagi suami dan anak-anak untuk lebih maju meraih keberhasilan di segala bidang dan mewujudkan cita-cita. ${ }^{11}$

Pasal 32 ayat (1) menentukan suami istri harus mempunyai tempat kediaman yang tetap. Tujuannya pengaturan Pasal ini menurut Moch. Isnaeni bahwa untuk memutar segala kewajiban dan hak suami istri secara berdampingan tentu saja diperlukan suatu tempat tinggal tertentu sebagai pelabuhannya, yakni berupa tempat tinggal atau domisili. ${ }^{12}$ Rumah tempat kediaman tersebut ditentukan oleh suami istri secara bersama, sebagaimana diatur dalam Pasal 32 ayat (2) Undang-Undang Perkawinan. Dari tempat tinggal yang ditentukan bersama suami istri itulah, segala kegiatan dimulai, dan di tempat tinggal itu pulalah segenap anggota keluarga akan berlabuh mengistirahatkan kepenatannya, ataupun membongkar hasil jerih payahnya untuk dinikmati bersama dalam perjamuan yang bernuansa teduh penuh kedamaian. ${ }^{13}$

Pasal 33 Undang-Undang Perkawinan menentukan suami istri wajib saling cinta-mencintai,hormat-menghormati, setia dan memberi bantuan lahir batin yang satu kepada yang lain. Ketentuan Pasal ini dapat dikatakan sebagai pondasi utama dalam perkawinan. Agar tujuan perkawinan tercapai dan kehidupan perkawinan berlangsung hingga maut memisah-

\footnotetext{
$10 \quad$ Moch. Isnaeni, Op. Cit. 186.

11 Moerti Hadiati Soeroso, Kekerasan Dalam Rumah Tangga Dalam Perspektif Yuridis -Viktimologis (Sinar Grafika 2011) 56.

12 Moch. Isnaeni, Op. Cit. 184.

13 Ibid.
} 
kan maka diperlukan rasa saling mencintai, saling menghormati, saling setia, dan saling membantu secara lahir batin satu sama lain sehingga harus ada rasa saling mengalah dan tidak mengutamakan ego dalam diri sendiri.

Pasal 34 ayat (1) menentukan suami wajib melindungi istrinya dan memberikan segala sesuatu keperluan hidup berumah tangga sesuai dengan kemampuannya. Pasal 34 ayat (1) lebih berfokus tentang hak nafkah untuk istri. Seorang suami memiliki kewajiban untuk memberikan nafkah secara penuh kepada istrinya yang berupa nafkah makan, minum, pakaian, dan tempat tinggal yang sesuai dengan kondisi sosial istri dan kemampuan finansial suami, tanpa membedakan antara istri yang muslimah ataupun yang non muslimah. ${ }^{14}$ Sedangkan kewajiban istri adalah mengatur urusan rumah tangga sebaik-baiknya sebagaimana diatur Pasal 34 ayat (2), artinya kewajiban istri lebih berfokus pada intern keluarga atau urusan domestik dalam rumah tangga yang salah satu contohnya adalah mengasuh dan mendidik anak. Namun seiring perkembangan jaman karena alasan ekonomi seorang istri juga bekerja membantu suami mencari nafkah, sehingga istri berfokus pada 2 hal yaitu bukan hanya pada intern keluarga namun juga pada ekstern.

Terkait dengan hak kepemilikan atas harta benda Pasal 35 ayat (2) menentukan harta bawaan dari masing-masing suami atau istri dan harta benda yang diperoleh masingmasing sebagai hadiah atau warisan adalah di bawah penguasaan masingmasing sepanjang para pihak tidak menentukan lain. Pengaturan lebih lanjut terkait penguasaan terhadap harta bawaan masing-masing ada dalam Pasal 36 ayat (2) bahwa mengenai harta bawaan masing-masing, suami istri mempunyai hak sepenuhnya untuk melakukan perbuatan hukum mengenai harta bendanya. Artinya pihak suami atau istri mempunyai hak secara penuh untuk mengurus harta bendanya yang dibawa masing-masing ke dalam perkawinan tanpa ada campur tangan dari pihak suami atau istri. Sedangkan untuk harta bersama pihak suami atau istri dapat bertindak dengan ada persetujuan dari kedua belah pihak yang pengaturannya ada dalam Pasal 36 ayat (1).

\section{Bentuk Kekerasan Yang Dialami Istri}

Sebelum membahas bentuk kekerasan, perlu dipahami terlebih dahulu pengertian dari kekerasan yang diatur Undang-Undang Penghapusan Kekerasan Dalam Rumah tangga dalam Pasal 1 angka 1 yang dimaksud dengan kekerasan adalah setiap perbuatan terhadap seseorang terutama perempuan, yang berakibat timbulnya kesengsaraan atau penderitaan secara fisik, seksual, psikologis, dan atau penelantaraan rumah tangga termasuk ancaman untuk melakukan perbuatan, pemaksaan, atau perampasan kemer- 
dekaan secara melawan hukum dalam lingkup rumah tangga. Berdasarkan pengertian tersebut dapat diketahui unsur dari terjadinya kekerasan adalah jika ada perbuatan dari pelaku yang mengakibatkan kesengsaraan atau penderitaan pada korban terutama korbannya seorang perempuan dengan jenis kekerasan terdiri kekerasan fisik, kekerasan seksual, kekerasan psikologis, dan penelantaran rumah tangga.

Sedangkan yang dimaksud dengan korban dalam Undang-Undang Penghapusan Kekerasan Dalam Rumah Tangga Pasal 1 angka 4 adalah orang yang mengalami kekerasan dan/atau ancaman kekerasan dalam lingkup rumah tangga. Dengan demikian dapat diketahui batasan korban kekerasan dalam rumah tangga jelas hanya dalam ruang lingkup rumah tangga saja. Ruang lingkup rumah tangga yang dimaksud dalam Undang-Undang Penghapusan Kekerasan Dalam Rumah Tangga yang diatur Pasal 2 ayat (1) adalah (a) suami, istri, dan anak; (b) orang-orang yang mempunyai hubungan keluarga dengan orang sebagaimana dimaksud pada huruf a karena hubungan darah, perkawinan, persusuan, pengasuhan, dan perwalian, yang menetap dalam rumah tangga, dan/atau; (c) orang yang bekerja membantu rumah tangga dan menetap dalam rumah tangga tersebut.
Sumber munculnya kekerasan berkaitan dengan aspek kultural yang patriarki, aspek struktural yang dominatif, eksploitatif akibat posisi tawar laki-laki dan perempuan tidak seimbang, sehingga realisasi jasmani dan mental psikologis aktualnya berada di bawah realisasi potensialnya. ${ }^{15}$ Istri yang menjadi korban kekerasan dalam rumah tangga dengan pelaku suami sendiri dapat terjadi karena adanya sistem patriarki dalam keluarga, dimana ada dominasi suami dalam kehidupan berumah tangga. Sistem patriarki yang ada dalam kehidupan berumah tangga menyebabkan suami dengan mudah dapat melakukan tindak kekerasan baik secara fisik maupun psikologis. ${ }^{16}$ Sistem patriarki ini bisa menjadi salah satu penyebab lemahnya sistem hukum nasional kita dalam menindak suami yang merupakan pelaku kekerasan dalam rumah tangga, seperti pendapat dari Moerti Hadiati Soeroso hal ini bisa terjadi salah satu penyebabnya sistem hukum nasional kita baik dari segi substansinya, sikap para penegak hukumnya maupun sikap masyarakat masih menganggap kekerasan terhadap perempuan dipandang sama dengan jenis-jenis kejahatan pada umumnya, bahkan dalam banyak hal aparat penegak hukum dan masyarakat cenderung melihat jenis kekerasan ini sebagai kesalahan kaum perempuan

\footnotetext{
15 M. Munandar Sulaeman dan Siti Homzah, Kekerasan Terhadap Perempuan: Tinjauan Dalam Berbagai Disiplin Imu dan Kasus Kekerasan (Refika Aditama 2010) 28.

16 Ibid.4.
} 
sendiri berikut mitos-mitos yang menyertainya. ${ }^{17}$

Dari banyaknya kasus kekerasan yang terjadi, dapat dikelompokkan bentuk-bentuk kekerasan dalam rumah tangga menjadi 4 kelompok yaitu: ${ }^{18}$ (1) kekerasan fisik yang terdiri dari pembunuhan, penganiayaan, pemerkosaan; (2) kekerasan non fisik/psikis/ emosional seperti penghinaan, komentar-komentar yang dimaksudkan untuk merendahkan dan melukai harga diri pihak istri, melarang istri bergaul, ancaman-ancaman berupa akan mengembalikan istri ke orang tua, akan menceraikan, memisahkan istri dari anak-anaknya dan lain-lain; (3) kekerasan seksual yang meliputi pengisolasian istri dari kebutuhan batinnya, pemaksaan hubungan seksual dengan pola yang tidak dikehendaki atau disetujui oleh istri, pemaksaan hubungan seksual ketika istri tidak menghendaki, istri sedang sakit atau menstruasi, memaksa istri menjadi pelacur dan sebagainya; (4) kekerasan ekonomi yang berupa tidak memberi nafkah pada istri, memanfaatkan ketergantungan istri secara ekonomis untuk mengontrol kehidupan istri, membiarkan istri bekerja untuk kemudian penghasilannya dikuasai suami misalnya memaksa istri menjadi "wanita panggilan".

Berdasarkan ketentuan Pasal 5 Undang-Undang Penghapusan Kekerasan Dalam Rumah Tangga diketahui jenis kekerasan dalam rumah tangga

Moerti Hadiati Soeroso, Op.Cit. 7. Ibid. 80-82. ada 4, yaitu kekerasan fisik; kekerasan psikis; kekerasan seksual; atau penelantaraan rumah tangga. Yang dimaksud dengan kekerasan fisik dalam Pasal 6 adalah perbuatan yang mengakibatkan rasa sakit, jatuh sakit, atau luka berat. Yang dimaksud dengan kekerasan psikis diatur dalam Pasal 7 adalah perbuatan yang mengakibatkan ketakutan, hilangnya rasa percaya diri, hilangnya kemampuan untuk bertindak, rasa tidak berdaya, dan/atau penderitaan psikis berat pada seseorang.

Mengenai kekerasan seksual dalam Pasal 8 meliputi: (a) pemaksaan hubungan seksual yang dilakukan terhadap orang yang menetap dalam lingkup rumah tangga tersebut; (b) pemaksaan hubungan seksual terhadap salah seorang dalam lingkup rumah tangganya dengan orang lain untuk tujuan komersial dan/atau tujuan tertentu. Sedangkan yang dimaksud penelantaran rumah tangga secara spesifik dalam Pasal 9 ayat (1) adalah orang yang melanggar kewajibannya, yang seharusnya pelaku berkewajiban memberikan kehidupan, perawatan, atau pemeliharaan kepada orang. Dikarenakan terjadinya penelantaran rumah tangga ini akibatnya diatur dalam Pasal 9 ayat (2) yaitu mengakibatkan ketergantungan ekonomi dengan cara membatasi dan/ atau melarang untuk bekerja yang layak di dalam atau di luar rumah sehingga korban berada di dalam kendali pelaku. 
Menurut Moerti Hadiati Soeroso, berdasarkan sebab terjadinya kekerasan dalam rumah tangga dapat dibagi menjadi 2 bagian yaitu: ${ }^{19}$ (1) kekerasan dalam rumah tangga sebagai perwujudan ekspresi ledakan emosional secara bertahap yang diawali dari terjadinya kekerasan non fisik mulai dari sikap dan perilaku yang tidak dikehendaki, maupun lontaran-lontaran ucapan yang menyakitkan dan ditujukan pada anggota keluarga yang lain. Proses ini akan berlanjut sehingga terjadi penimbunan kekecewaan, kekesalan dan kemarahan yang pada akhirnya menjurus pada kekerasan fisik; (2) kekerasan dalam rumah tangga sebagai perwujudan ekspresi ledakan emosional spontan adalah bentuk kekerasan yang dilakukan tanpa ada perencanaan terlebih dahulu, terjadi secara seketika (spontan) tanpa didukung latar belakang peristiwa yang lengkap. Ledakan emosi yang timbul begitu cepat sehingga kekuatan akal pikiran untuk mengendalikan diri dikalahkan oleh nafsu atau emosi yang memuncak, kemudian yang bersangkutan memberikan reaksi keras dengan melakukan perbuatan dalam bentuk tindak pidana lain berupa penganiayaan atau pembunuhan terhadap anggota keluarga lainnya.

\section{Sanksi Bagi Suami Pelaku Tindak Kekerasan}

Setiap orang yang melakukan tindak kekerasan akan mendapatkan

Ibid. 82 - 83.

Ibid. 133. sanksi pidana, demikian juga seorang suami yang melakukan tindak kekerasan terhadap istrinya. Bukan hal mudah untuk mengungkap tindakan kekerasan dalam rumah tangga yang menjadikan istri sebagai korban karena adanya anggapan terjadinya kekerasan dalam rumah tangga merupakan masalah intern, sehingga akan menjadi aib keluarga apabila istri melaporkan tindakan suami kepada pihak kepolisian. Rasa segan untuk melapor dan mengungkapkan tindak kekerasan yang terjadi dikarenakan adanya mitos yang berkembang di masyarakat bahwa kekerasan dalam rumah tangga adalah urusan keluarga itu sendiri, sehingga masyarakat tidak mau dianggap mencampuri urusan rumah tangga orang lain. ${ }^{20}$

Sebelum adanya Undang-Undang Penghapusan Kekerasan Dalam Rumah Tangga, pengaturan sanksi pidana mengenai kekerasan dalam rumah tangga diatur dalam Kitab UndangUndang Hukum Pidana (selanjutnya disingkat dengan KUHPidana). Menurut Moerti Hadiati Soeroso, dalam hal penganiayaan terhadap istri (domestic violence) KUHPidana memberikan pemberatan hukuman, namun $\mathrm{KUH}$ Pidana tidak mengaturnya dalam bab atau Pasal tersendiri, melainkan sebagai bagian dari Pasal penganiayaan terhadap anggota keluarga. Selain itu KUHPidana hanya mengakui kekerasan fisik sebagai bentuk kejahatan tidak mempertimbangkan 
kekerasan psikis atau seksual. ${ }^{21}$ Kekerasan fisik dalam KUHPidana termasuk dalam tindak pidana penganiayaan sebagaimana diatur dalam Pasal 351 sampai 356 KUHPidana. Bentuk kekerasan psikis dalam KUH Pidana adalah penghinaan yang diatur dalam Pasal 310 sampai 321 KUHPidana. Dapat dikatakan pengesahan Undang-Undang Penghapusan Kekerasan Dalam Rumah Tangga ini menempatkan tindak kekerasan dalam rumah tangga sebagai tindak pidana khusus bukan lagi tindak pidana umum.

Seorang pelaku kekerasan fisik dalam rumah tangga berdasarkan ketentuan Pasal 44 ayat (1) dapat dipidana dengan pidana penjara paling lama 5 (lima) tahun atau denda paling banyak Rp. 15.000.000,- (lima belas juta rupiah), apabila terjadi kekerasan fisik ini mengakibatkan korban mendapatkan jatuh sakit atau luka berat maka dalam Pasal 44 ayat (2) menentukan pelaku dapat dipidana dengan pidana penjara paling lama 10 (sepuluh) tahun atau denda paling banyak Rp. 30.000.000,- (tiga puluh juta rupiah).

Sanksi pidana pelaku kekerasan fisik akan diperberat dalam Pasal 44 ayat (3) apabila mengakibatkan matinya korban dengan pidana penjara paling lama 15 (lima belas) tahun atau denda paling banyak Rp. 45.000.000,(empat puluh lima juta rupiah). Sanksi pelaku kekerasan fisik bisa diringan-

$21 \quad$ Ibid. 6. kan sebagaimana diatur dalam Pasal 44 ayat (4) apabila tindakan kekerasan fisik yang dilakukan suami terhadap istri tidak menimbulkan penyakit atau halangan untuk menjalankan pekerjaan jabatan atau mata pencaharian atau kegiatan sehari-hari dengan sanksi dipidana penjara paling lama 4 (empat) bulan atau denda paling banyak Rp. 5.000.000,- (lima juta rupiah).

Bagi pelaku kekerasan psikis berdasarkan ketentuan Pasal 45 ayat (1) dapat dipidana dengan pidana penjara paling lama 3 (tiga) tahun atau denda paling banyak Rp. 9.000.000,(Sembilan juta rupiah). Apabila kekerasan psikis yang dilakukan suami terhadap istri tidak menimbulkan penyakit atau halangan untuk menjalankan pekerjaan jabatan atau mata pencaharian atau kegiatan seharihari dalam Pasal 45 ayat (2) dapat dipidana penjara paling lama 4 (empat) bulan atau denda paling banyak Rp. 5.000.000,- (lima juta rupiah).

Pasal 46 menentukan bagi pelaku kekerasan seksual dengan cara pemaksaan hubungan seksual yang dilakukan terhadap orang yang menetap dalam lingkup rumah tangga sebagaimana dimaksud dalam Pasal 8 huruf a, maka dapat dipidana penjara paling lama 12 (dua) belas tahun atau denda paling banyak Rp. 36.000.000,- (tiga puluh enam juta rupiah). Sedangkan dalam Pasal 47 menentukan bagi pelaku kekeras-an seksual dengan cara pemaksaan hubungan seksual terhadap salah 
seorang dalam lingkup rumah tangganya dengan orang lain untuk tujuan komersial dan/atau tujuan tertentu sebagaimana dimaksud dalam Pasal 8 huruf $b$, maka dapat dipidana penjara paling lama 4 (empat) tahun dan pidana penjara paling lama 15 (lima belas) tahun atau denda paling sedikit Rp. 300.000.000,- (tiga ratus juta rupiah).

Pemberatan sanksi pelaku kekerasan seksual diatur dalam Pasal 48 yaitu apabila terjadinya kekerasan seksual ini mengakibatkan korban mendapat luka yang tidak memberi harapan akan sembuh sama sekali, mengalami gangguan daya pikir atau kejiwaan sekurang-kurangnya selama 4 (empat) minggu terus-menerus atau 1 (satu) tahun tidak berturut-turut, gugur atau matinya janin dalam kandungan, atau mengakibatkan tidak berfungsinya alat reproduksi maka dapat dipidana penjara paling singkat 5 (lima) tahun dan pidana penjara paling lama 20 (dua puluh) tahun atau denda paling sedikit Rp. 25.000.000,- (dua puluh lima juta rupiah) dan denda paling banyak Rp. 500.000.000,- (lima ratus juta rupiah).

Berkaitan dengan penelantaran dalam rumah tangga yang diatur dalam Pasal 9 ayat (1) dan ayat (2) dalam Pasal 49 menentukan pelaku penelantaran rumah tangga dapat dipidana penjara paling lama 3 (tiga) tahun atau denda paling banyak Rp. 15.000.000,- (lima belas juta rupiah). Ada pidana tambahan bagi pelaku kekerasan dalam rumah tangga secara keseluruhan yang diatur dalam Pasal 50 bahwa Hakim bisa: (a) pembatasan gerak pelaku baik yang bertujuan untuk menjauhkan pelaku dari korban dalam jarak dan waktu tertentu, maupun pembatasan hakhak tertentu dari pelaku; (b) penetapan pelaku mengikuti program konseling di bawah pengawas lembaga tertentu. Yang dimaksud lembaga tertentu dalam penjelasan Pasal 50 adalah lembaga yang sudah terakreditasi menyediakan konseling layanan bagi pelaku. Misalnya rumah sakit, klinik, kelompok konselor, atau yang mempunyai keahlian memberikan konseling bagi pelaku selama jangka waktu tertentu. Adanya pengaturan hukuman tambahan hanya dapat dijatuhkan bersama-sama dengan hukuman pokok, sehingga penjatuhan hukuman tambahan itu biasanya bersifat fakultatif dan Hakim tidak diharuskan menjatuhkan hukuman tambahan. ${ }^{22}$

Berdasarkan uraian tentang sanksi pidana pelaku kekerasan dalam rumah tangga tersebut di atas, dapat diketahui Undang-Undang Penghapusan Kekerasan Dalam Rumah Tangga menganut sistem alternatif dalam penerapan sanksi pidana, yang artinya memungkinkan Hakim untuk memilih sanksi pidana penjara atau pidana denda. Pengaturan sanksi pidana dalam Undang-Undang Penghapusan

22. Leden Marpaung, Asas Teori Praktik Hukum Pidana (Sinar Grafika 2008) 111. 
Kekerasan Dalam Rumah Tangga hanya mengatur sanksi pidana maksimal tanpa mengatur sanksi pidana minimal. Hanya ada satu pasal pengaturan sanksi pidana dalam UndangUndang Penghapusan Kekerasan Dalam Rumah Tangga yang secara tegas menentukan pengaturan sanksi pidana penjara atau pidana denda dengan ada batasan pengenaannya secara minimal dan maksimal yaitu Pasal 48 mengenai pemberatan sanksi pelaku kekerasan seksual yang mengakibatkan korban mendapat luka yang tidak memberi harapan akan sembuh sama sekali, mengalami gangguan daya pikir atau kejiwaan sekurangkurangnya selama 4 (empat) minggu terus-menerus atau 1 (satu) tahun tidak berturut-turut, gugur atau matinya janin dalam kandungan, atau mengakibatkan tidak berfungsinya alat reproduksi dengan sanksi pidana penjara paling singkat 5 (lima) tahun dan pidana penjara paling lama 20 (dua puluh) tahun atau denda paling sedikit Rp. 25.000.000,- (dua puluh lima juta rupiah) dan denda paling banyak Rp. 500.000.000,- (lima ratus juta rupiah).

Terjadinya kekerasan dalam rumah tangga, baik kekerasan fisik, kekerasan psikis, dan kekerasan seksual merupakan delik aduan sebagaimana diatur dalam Pasal 51, Pasal 52, dan Pasal 53. Adapun delik aduan adalah jenis perbuatan pidana yang baru dapat dilakukan penuntutan apabila

23 Moerti Hadiati Soeroso, Op.Cit. 93. ada pengaduan dari korban atau mereka yang dirugikan. ${ }^{23}$ Dengan demikian tanpa adanya pengaduan maka suatu tindak pidana tidak dapat dituntut. Jika melihat ketentuan Pasal 51, Pasal 52, dan Pasal 53 Undang-Undang Penghapusan Kekerasan Dalam Rumah Tangga maka pelaku tindak kekerasan dalam rumah tangga dapat dituntut apabila ada pengaduan dari korban, namun lebih lanjut Undang-Undang Penghapusan Kekerasan Dalam Rumah Tangga juga menganut delik biasa yang artinya apabila ada seseorang warga masyarakat yang mengetahui adanya korban dari tindak kekerasan dalam rumah tangga dan memiliki kepedulian untuk menolong maka dapat melaporkan ke pihak Kepolisian. Penegasan penganutan delik biasa dalam Undang-Undang Penghapusan Kekerasan Dalam Rumah Tangga ini tujuannya untuk meningkatkan peran serta masyarakat dalam mencegah terjadinya tindak kekerasan dalam rumah tangga yang pengaturannya ada dalam Pasal 15 bahwa setiap orang yang mendengar, melihat, atau mengetahui terjadinya kekerasan dalam rumah tangga wajib melakukan upaya-upaya sesuai dengan batas kemampuannya untuk (a) mencegah berlangsungnya tindak pidana; (b) memberikan perlindungan kepada korban; (c) memberikan pertolongan darurat; dan (d) membantu proses pengajuan permohonan penetapan perlindungan. 


\section{PENUTUP}

Berdasarkan uraian tersebut di atas maka dapat disimpulkan bahwa terjadinya kekerasan dalam rumah tangga menunjukkan tidak seimbangnya kedudukan suami istri dalam menjalani kehidupan berumah tangga. Sistem patriarki dalam kehidupan berumah tangga yang artinya menunjukkan posisi suami paling dominan dalam keluarga dapat menyebabkan istri menjadi korban kekerasan dalam rumah tangga. Padahal seharusnya ada keseimbangan hak dan kewajiban antara suami istri agar tujuan perkawinan yang ditentukan Pasal 1 Undang-Undang Perkawinan bisa tercapai. Pemerintah Indonesia sudah mengesahkan Undang-Undang Penghapusan Kekerasan Dalam Rumah Tangga, namun dalam rangka mencegah terjadinya kekerasan dalam rumah tangga harus dipahami terlebih dahulu tentang hak dan kewajiban yang harus dijalankan bersama antara suami istri.

Keseimbangan hak dan kewajiban suami istri yang diatur dalam UndangUndang Perkawinan tidak hanya tentang kehidupan intern dalam rumah tangga, tetapi juga kehidupan ekstern yaitu dalam hidup bermasyarakat suami istri mempunyai hak dan kewajiban yang seimbang. Dahulu posisi istri selalu diidentikkan dengan urusan intern seperti mengasuh dan mendidik anak, namun seiring perkembangan jaman pada saat ini istri dapat bekerja dengan mengoptimal- kan segala kemampuan yang dimiliki, sehingga istri tidak hanya mengurusi urusan intern namun juga urusan ekstern yang berkaitan dengan pekerjaan.

Bentuk kekerasan dalam rumah tangga yang diatur dalam Pasal 5 Undang-Undang Penghapusan Kekerasan Dalam Rumah Tangga adalah kekerasan fisik; kekerasan psikis; kekerasan seksual; atau penelantaraan rumah tangga. Terjadinya tindak kekerasan dalam rumah tangga dengan pelaku suami menimbulkan kerugian pada istri, oleh sebab itu ada sanksi pidana yang akan dikenakan pada suami apabila terbukti melakukan tindak kekerasan terhadap istri. Sebelum adanya Undang-Undang Penghapusan Kekerasan Dalam Rumah Tangga pengaturan sanksi pidana tindak kekerasan ini ada dalam KUHPidana, namun dengan berlakunya Undang-Undang Penghapusan Kekerasan Dalam Rumah Tangga menunjukkan tindak pidana kekerasan dalam rumah tangga sebagai tindak pidana khusus bukan tindak pidana umum sebagaimana diatur dalam KUHPidana.

Pengenaan sanksi pidana pada suami sebagai pelaku tindak kekerasan dalam rumah tangga diharapkan bisa memberikan efek jera bagi pelaku agar tidak mengulangi perbuatannya lagi, namun sayangnya pengaturan sanksi pidana dalam Undang-Undang Penghapusan Kekerasan Dalam Rumah Tangga menganut sistem alternatif yaitu Hakim dimungkinkan memilih 
menjatuhkan putusan pidana penjara atau pidana denda dengan hanya pengaturan pidana maksimal saja tanpa pengaturan pidana minimal. Pengaturan sanksi pidana minimal dan maksimal hanya ada pengaturan dalam Pasal 48.

Pasal 51, Pasal 52, dan Pasal 53 Undang-Undang Penghapusan Rumah Tangga menganut delik aduan, yang artinya suami sebagai pelaku kekerasan dalam rumah tangga dituntut pidana apabila ada aduan dari korban, namun tidak menutup juga terjadinya kekerasan dalam rumah tangga ini sebagai delik biasa yaitu apabila ada warga masyarakat yang mengetahui adanya korban dari tindak kekerasan dalam rumah tangga dan memiliki kepedulian untuk menolong dapat melaporkannya ke pihak Kepolisian karena ini menunjukkan peran serta masyarakat dalam mencegah terjadinya kekerasan dalam rumah tangga di sekitar lingkungan tempat tinggalnya sebagaimana diatur dalam Pasal 15 Undang-Undang Penghapusan Rumah Tangga. Dalam rangka mencegah terjadinya tindak kekerasan dalam rumah tangga yang dilakukan oleh suami dengan korban istri, maka ada beberapa saran yang dapat dilakukan yaitu:

1. Sebelum terjadinya perkawinan, bagi pasangan calon suami istri perlu diberikan pembekalan materi tentang hak dan kewajiban suami istri yang diberikan oleh Kantor Urusan Agama atau Kantor Catatan Sipil tempat perkawinannya hendak dicatatkan. Tujuannya agar ada pemahaman tentang hak dan kewajiban yang lahir setelah terjadinya perkawinan bagi kedua belah pihak;

2. Sosialisasi Undang-Undang Penghapusan Kekerasan Dalam Rumah Tangga agar masyarakat memahami bahwa terjadinya tindak kekerasan dalam rumah tangga merupakan perbuatan pidana yang dapat dijatuhkan sanksi pidana, sehingga apabila menjadi korban atau melihat ada korban kekerasan dalam rumah tangga diharapkan berani melaporkan kepada pihak kepolisian agar bisa diproses secara hukum;

3. Ada perbaikan pengaturan tentang sanksi pidana dalam UndangUndang Penghapusan Kekerasan Dalam Rumah Tangga dengan bukan menganut sistem alternatif namun sistem kumulatif dengan ketegasan pengaturan pidana bukan hanya mengatur sanksi pidana maksimal tetapi juga sanksi pidana minimalnya yang ditentukan secara tegas.

\section{DAFTAR BACAAN}

\section{Buku}

H.S., Salim, Pengantar Hukum Perdata Tertulis (BW) (Sinar Grafika 2014).

Isnaeni, Moch., Hukum Perkawinan Indonesia (Revka Petra Media 2016). 
Kaharuddin, Nilai-Nilai Filosofi Perkawinan Menurut Hukum Perkawinan Islam dan Undang-Undang RI Nomor 1 Tahun 1974 tentang Perkawinan (Mitra Wacana Media 2015).

Marpaung, Leden, Asas Teori Praktik Hukum Pidana (Sinar Grafika 2008).

Setiawan, I Ketut Oka, Hukum Perorangan dan Kebendaan (Sinar Grafika 2016).

Soeroso, Moerti Hadiati, Kekerasan Dalam Rumah Tangga Dalam Perspektif Yuridis - Viktimologis (Sinar Grafika 2011).

Sulaeman, M. Munandar dan Siti Homzah, Kekerasan Terhadap Perempuan: Tinjauan Dalam Berbagai Disiplin Ilmu dan Kasus Kekerasan (Refika Aditama 2010).

Syaifuddin, Muhammad, dkk., Hukum Perceraian (Sinar Grafika 2016).

\section{Peraturan Perundang-Undangan}

Undang-Undang Dasar 1945.

Undang-Undang Nomor 1 Tahun 1974 tentang Perkawinan.

Undang-Undang Nomor 39 Tahun 1999 tentang Hak Asasi Manusia.

Undang-Undang Nomor 23 Tahun 2004 tentang Penghapusan Kekerasan Dalam Rumah Tangga. 
